\title{
THE BORDER AS A RESOURCE FOR THE DEVELOPMENT OF BORDERLAND: A COMPARATIVE ANALYSIS OF TWO POLISH URBAN CENTRES AT THE EXTERNAL BORDER OF THE EUROPEAN UNION
}

\author{
Dominika StUdZIŃSKA ${ }^{1}$, StanisŁaW DomanieWSKI ${ }^{2}$ \\ ${ }^{1}$ Department of Economic Geography, University of Gdańsk, Poland \\ ${ }^{2}$ Karelian Institute, University of Eastern Finland, Joensuu, Finland
}

Manuscript received: July 29, 2015

Revised version: October 7, 2016

\begin{abstract}
StUDZiŃSKA D., DomANIEWSKI S., 2016. The border as a resource for the development of borderland: A comparative analysis of two Polish urban centres at the external border of the European Union. Quaestiones Geographicae 35(4), Bogucki Wydawnictwo Naukowe, Poznań, pp. 145-155, 6 figs.

AвSTRACT: The entry into force of the Agreement between the Republic of Poland and the Russian Federation on visa-free movement in 2012 caused an increase in border permeability, and hence a sudden increase in border crossings. The border which used to divide the neighbouring states started linking them instead. Crossing the border became part of the everyday life of local communities. Actors on both sides benefited from the commercial services of the other country. For Kaliningrad citizens, border-crossing points became gates to Europe, and for Poles, a resource improving the quality of life via petty trade. The aim of this article is to compare two border cities: Braniewo, a town located in the immediate vicinity of the border-crossing point, and Tri-City, which has become a new border centre after the introduction of small border traffic. Two viewpoints on the effect of local border traffic are presented. The first is the perspective of a typical border city. The other is that of the effect of an increase in border permeability on a major urban centre - Tri-City.
\end{abstract}

KEY wORDS: Polish-Russian border, borderland, Braniewo, Tri-City, Kaliningrad Oblast

Corresponding author: Dominika Studzińska, Chair of Economic Geography, University of Gdańsk, ul. Bażyńskiego 4, 80-309 Gdańsk, Poland; e-mail: geods@univ.gda.pl.

\section{Introduction}

This paper will discuss how different-sized towns in northern Poland deal with heavier border traffic. This increase is due to the loosening of visa regulations since 2012 on the Polish-Russian border and the creation of the so-called small border traffic (SBT) zone. This is the only visa-free system between an EU member state and the Russian Federation. This paper examines whether the border, which Sohn (2014) argues plays a role as a resource, can also be seen as creating an uneven playing field for those involved. The use of this resource by some municipalities creates multiple competing strategies which offer uncertain outcomes for its development equally and advantageously for all. It will also be claimed that the border would be a better-managed resource for all involved parties if actors with similar issues cooperated with one another to achieve solutions.

There is currently a debate going on in municipalities along the northern Polish-Russian 
border. The opening of the border has led to increased commercial activity and a rise in other services on offer in both small and large Polish border towns. In many small towns this increase is sometimes twice what the local population needs. Shops and storefronts cater to the foreign clientele, and an increasing number of retailers cash in on this lucrative trade. Also the area's larger towns and cities expand their sales and services, offering a more varied choice of both, everyday and luxury items and services to those crossing the border.

This article will present two examples of urban centres that are currently within the SBT zone: Braniewo and the Tri-City of Gdańsk, Gdynia and Sopot. Both are popular with residents of the Kaliningrad Oblast (region) for day visits or overnight stays. The development of Braniewo, with a population of 18,000 , has been influenced by the increase in border permeability and price differences between the two sides of the border. In turn, Tri-City, with a population of 747,000 , is the main urban centre of northern Poland. Although it benefits from visits of Kaliningrad residents, it does not rely on them alone for a sustainable economy. The area is well known throughout the region and neighbouring countries for its cultural attractions and amenities. Visiting both areas has become one of the main aims for Russians crossing the border. However, reasons for visiting and the duration of each visit differ. The way in which both towns deal with those visits differs as well.

\section{Methods}

This paper is based on the authors' own research conducted under the EUBORDERSCAPES project supported by the European Commission. Between 2013 and 2014, the authors gathered material in both Tri-City and Braniewo. Interviews were conducted with local residents and business owners. Fourteen semi-structured interviews were carried out in Tri-City. The authors interviewed workers at the Pomeranian Marshall's Office and the city halls of Gdańsk and Gdynia, managers of hotels and shopping centres, and workers at Tri-City tourist attractions. Their comments were supplemented by a survey conducted in 2013 among Russian tourists $(n=462)$ visiting Tri-City. Respondents were asked about Tri-City's attractiveness and the role of the Small Border Traffic Agreement in their cross-border activity. In addition, in 2013 a survey was conducted of the attitudes of Tri-City residents ( $\mathrm{n}=$ 402) towards the Kaliningrad Oblast and Russian tourists. The authors also used the results of a survey of Russian tourists in Gdańsk conducted by the Gdańsk city hall in June and July 2013.

In Braniewo, twenty expert interviews were conducted to investigate the impact of the changing border permeability on the development of the town, as well as to gather various perspectives concerning the small border traffic zone. Participants were recruited using the snowball method. Additionally, fieldwork, including participant observation, was conducted in July 2013.

\section{Theoretical framework}

A border can be defined as both a dividing line and a contact zone. Many national borders are currently subject to transformation as a result of economic globalisation (Donnan, Wilson 1999). Following the formation of the European Community, there was a change in the function of internal European Union borders from lines delineating the sovereignty of states into areas for meetings and the cooperation of regions (Opioła, Trzcielińska-Polus 2013). The dividing function of borders is weakening, and there is a tendency for them to become increasingly permeable. They constitute spaces of mutual permeation and the joining of regions and local communities (Heffner 2010).

As a result of their gradual opening and the weakening of their separating function, borders are becoming gates for the movement of people and goods. Moreover, they also constitute an important stimulus for the development of border towns (Sohn 2014). Through them local communities gain access to cheaper or unavailable products. This improves individuals' financial situations (Hanson 1998). Border areas, apart from profiting from their location, can also make use of diversity arising from the two sides of the border, taking advantage of differences in prices, rules and regulations, and norms (i.e. differential benefits) (Sohn 2014). Moreover, borders create differences that either encourage or discourage 
individuals from crossing them (Spierings, Van der Velde 2008). However, differences between the two sides of the border offer the possibility of creating new solutions in the planning and development of towns (Sohn 2014). An example can be seen in joint actions undertaken for the development of border towns in the EU. Those actions are implemented more easily along the EU's internal borders because of their high level of accessibility and permeability.

Sohn (2014) also states that the opening of borders results in an increase in familiarity with a region because of the sudden development of cross-border activities. Border towns attract the interest of media and politicians. Likewise, local entrepreneurs tend to become international entrepreneurs. The unique location of towns on a border can constitute the main development factor in border regions. Where the transformation of the border function through an increase in its permeability is concerned, the location is a resource for local communities.

\section{The Polish-Russian borderland after the fall of communism}

Until 1990 the northern border between Poland and the USSR was practically impassable. The only transport that could cross it was registered military freight train traffic at the Gronowo and Bezledy checkpoints. Only government delegations were permitted to use road crossing points (Komornicki 1999). The fall of communism and the breakup of the Soviet Union have not only created a new border regime between Poland, Lithuania and the newly created Russian Federation, but also led to establishing an exclave in the Kaliningrad Region.

Until 1998 the Polish-Russian border did not constitute a significant obstacle for travel between the two countries. The situation changed after the tightening of Polish law in December 1997 (the new Foreigners Act) and Russian laws based on special forms for the implementation of invitations and vouchers guaranteeing hotel services.

With the accession of Poland to the EU, the Polish-Russian border became a de jure external border of the European Union. At the same time it became a barrier. In October 2003 an agreement between the Republic of Poland and the Russian Federation came into force. It dealt with travelling conditions for Polish and Russian citizens. The new policy mandates put in place a programme of bureaucratic requirements for travel visas between Poland and Russia. Until 1 June 2007, Polish and Kaliningrad Oblast citizens had the right to a visa free of charge; then they were obliged to pay for a visa, creating extra costs and increasing the time spent by individuals crossing the border. This caused a decrease in border-crossing activity. There were some 3 million crossings in 2007, and approximately 1.2 million in 2009 (Fig. 1). To ameliorate for the further isolation of the Kaliningrad Oblast caused by the accession of Poland and Lithuania to the Schengen Area in 2007, visa requirements for the

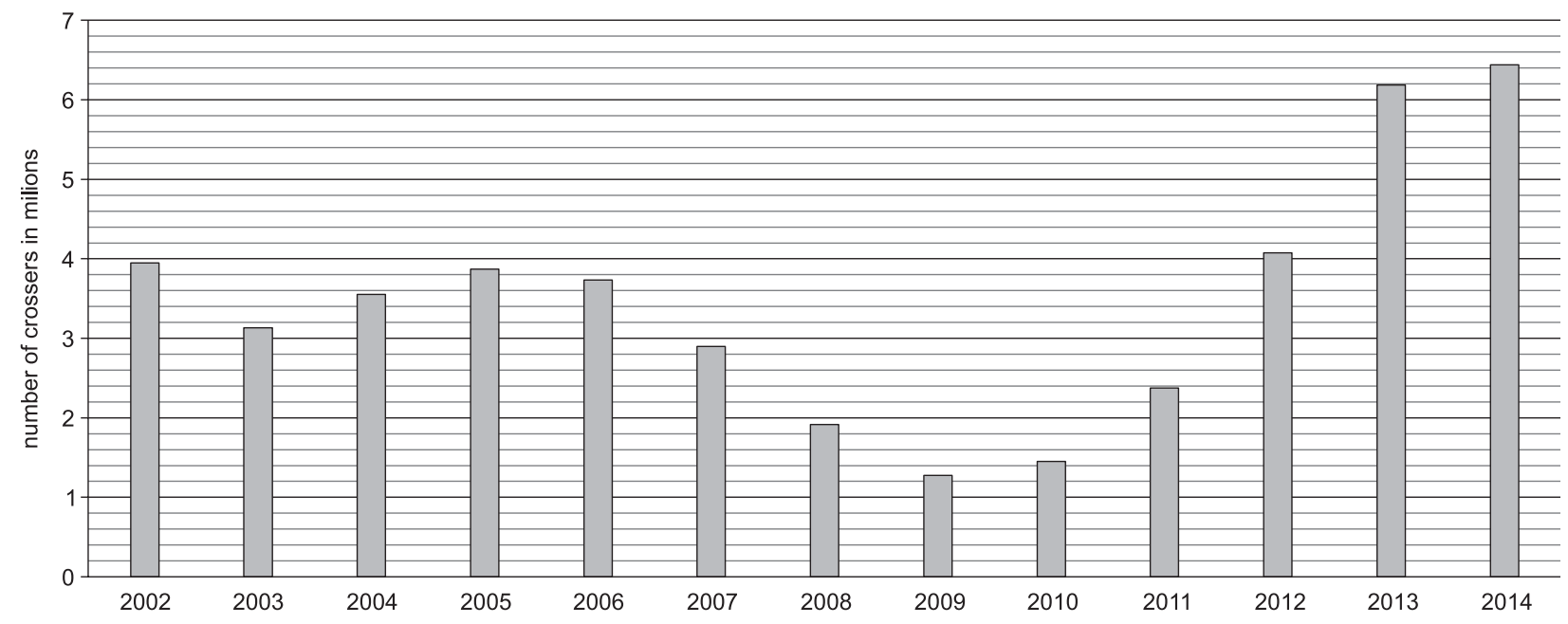

Fig. 1. Border traffic between Poland and the Kaliningrad Oblast in the years 2002-2014. Source: estimates based on data from Border Guard 2015. 
Polish-Russian borderland have been covered by the SBT zone. After it was established, the number of people crossing the border has increased.

Under the EU regulations, small border traffic is defined as a regular crossing of the external land border of the European Community by individuals inhabiting a defined border area. An individual must state that they are specifically visiting the neighbouring country for social, cultural, or family reasons, or have a justified economic reason to stay in the specified area. The duration of the visit may not exceed three months. At first, areas located not further than 30 $\mathrm{km}$ from the border (in special cases $50 \mathrm{~km}$ ) were recognised as being in the border zone. People inhabiting areas involved in the visa-free regime for more than one year were eligible to be considered residents of the zone and could freely cross the border without a visa.

As part of the SBT agreement between Poland and Russia, those areas were considerably expanded beyond what the EU had envisioned. The expansion included the entire Kaliningrad Oblast, a sizable part of Pomeranian and Warmia-Mazuria voivodeships, the Tri-City agglomeration of Gdańsk, Gdynia, and Sopot, and the city of Olsztyn included in both voivodeships (Fig. 2). Residents of the Polish-Russian border region could obtain permission to freely cross the border for an initial period of two, and later five, years. Obtaining permission for visa-free movements costs $€ 20$. This is lower than the cost of a Schengen or a Russian Federation visa (the regular price for a Schengen single-entry visa is $€ 35)$. The creation of the SBT zone in the PolishRussian borderland required some concessions from both the EU and the Russian Federation. The SBT zone would be a step towards a complete abolition of EU visa schemes for Russia. In turn, the EU agreed to a visa-free zone larger than previously regulated. After the implementation of the agreement, the SBT zone contributed to a considerable increase in Polish-Russian cross-border activity. In 2013 the number of border crossings was five times higher than in 2009.

After the agreement on visa-free movement had come into force, the borderlands experienced a socio-economic revival of sorts. This was especially evident on the Polish side, which saw dramatic changes after 2012. New investments

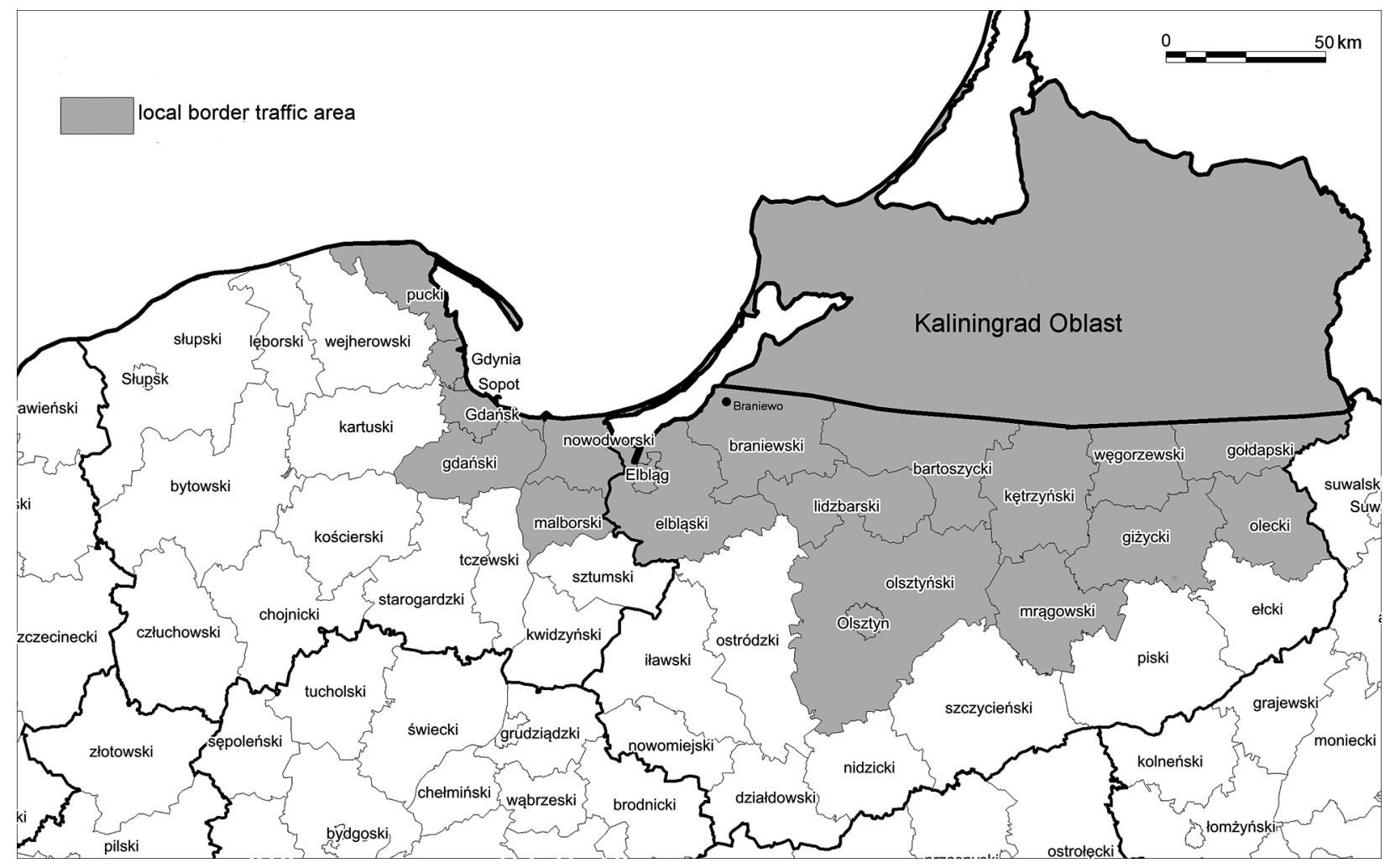

Fig. 2. Visa-free zone at the Polish-Russian border.

Source: own elaboration based on Agreement between the Government of the Republic of Poland and the Government of the Russian Federation on the Rules of Local Border Traffic enacted in 2012. 
(hotels, shops, spas, and wellness centres) began to cater more to new Russian clients, with signs and advertisements in both Polish and Russian. As road traffic began to increase, more businesses opened offering tax and VAT discounts to Russian tourists. A growing number of Russian cars could be seen parked in front of discount stores and tourist attractions on the Polish side of the border. All this is indicative of the significant impact of the SBT regime.

The involvement of so many districts on the Polish side in the visa-free project has contributed to uneven development. Although the majority of those areas could feel the benefits of local border traffic after 2012, not all profited to the same extent. The greatest benefits were felt by towns located in the immediate vicinity of border-crossing points (Gołdap, Braniewo and Bartoszyce), popular tourist destinations (Mikołajki, Lidzbark Warmiński, etc.), and major cities (Tri-City, Olsztyn and Elbląg). Moreover, there was noticeable competition among local government units for Russian customers. In larger towns the development of different forms of infrastructure, the number/scale of tourist attractions, and their human and social capital was more diversified. The strongest centres therefore received more Russian tourists. According to Dudzińska and Dyner (2013), Tri-City profited most after the regime came into force. Other border towns sought to imitate actions taken by the agglomeration's local authorities and entrepreneurs.

Two examples of how towns have developed under the influence of increased border permeability, those of Tri-City and Braniewo, will be introduced in the next section.

\section{Braniewo: the resurgence of a small border town}

Braniewo is a town located $6 \mathrm{~km}$ south of the Polish-Russian border. A major border crossing point is located directly outside the town's limits. During the Cold War the town was known for its Polish army bases and served as a military supply rail route to and from the Kaliningrad region. Until the 1990s the town saw frequent visits of Russian soldiers, but had no formal border crossing to Russia or to the city of Kaliningrad, some $50 \mathrm{~km}$ away. As happened in much of the region after the Cold War had ended, army bases near the town began to be closed, and individuals in state-run companies began to lose work. During this period few tourists were to be found crossing the border after its opening in 1991.

The numbers crossing from Kaliningrad to Poland grew slowly but steadily in the 1990s and 2000s. During this period the town had little growth to speak of beyond what was needed in terms of shopping choices or infrastructure. The implementation of the SBT zone in 2012 brought about several changes in the town. Many of them were ideas borrowed from larger municipalities such as Tri-City, while others were strategic initiatives arising from the distance to and from the border.

Because of its proximity to the border crossing on the main road to Kaliningrad, Braniewo is promoted as the first and often only stop for many tourists. The town has seen an explosion of both shopping and service options, often characterised by a local flair. Like many shops in the Tri-City area, the town offers advertising in both Russian and Polish. Many shops in Braniewo also have a Russian name. This can often explain the service or products to be found in the establishment (Fig. 3); and even one of the local restaurants has a Russian name. Also, a number of translation services and language schools offer the Russian language to a growing number of individuals. Several restaurants advertise in Russian on road signs, and many also offer menus in Russian.

There is also a growing number of large discount stores in the town. The desire to be the

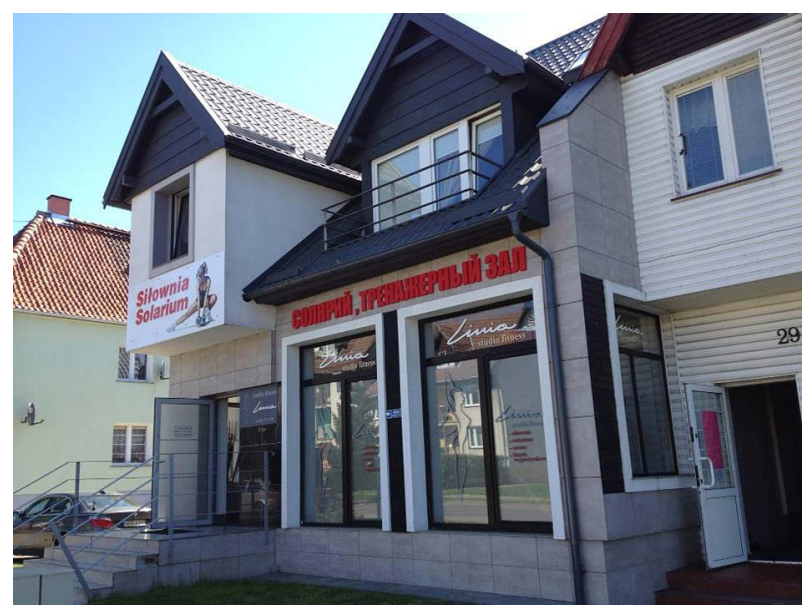

Fig. 3. 'Solarium and Gym' for women with a Russian translation of the name. Source: own collection. 
first stop on a tourist's route has resulted in these shops inching closer and closer towards the border-crossing point outside the town. Recently, the Biedronka discount food retailer opened a fourth shop in the town, having torn down its first shop, built in the 2000s. It was reopened as a larger and more spacious place under the same name. Other major discount food chains, such as Lidl, and several large electronics shops, like Media Expert, have also opened shops in the town. There are also large garden and agricultural machinery shops here.

Local entrepreneurs have also expanded their businesses in a number of ways. Many businesses have begun to cater to a spa clientele. A local hotelier has expanded his business by building a second hotel catering to 'health \& wellness' customers. He has also expanded his original hotel as a venue for weddings and other formal parties. Likewise, many of the larger chain stores and small to medium local stores, for example furniture shops and clothing retailers, have expanded their storefront or opened a second larger store. The town itself has also expanded its services. Town parks and services have been noticeably improved. Many roads near the town have been repaved and roundabouts are better maintained.

Many residents of Braniewo rely heavily on border traffic and price differences for their wider economic needs. For Poles, a visit to Kaliningrad offers an opportunity to conduct petty trade in petrol, alcohol and cigarettes. Those involved in such trade, called 'ants' in the local slang, travel between Kaliningrad and Poland several times a week. They can often supplement a family's income by as much as $30 \%$ to $40 \%$ from this illegal but very open and public petty gasoline trade. The respondents stated that they went to Kaliningrad almost exclusively for this trade and stayed no more than an hour, plus the time it took to cross the border (Studzińska, Nowicka 2014). They often never drove past the petrol station a few kilometres away from the border area. The principle of staying for as short a time as possible has been reinforced since a spate of attacks on Polish petrol traders in Kaliningrad in May 2015 (Poles in Kaliningrad 2015).

Similarly, Kaliningrad residents usually stay in Braniewo for only a few hours. Those who stay overnight often do so because they arrive late in the evening, usually because of the long queues on the Russian side of the border that can sometimes stretch for several kilometres (Studzińska, Nowicka 2014). When interviewed, a local businessman said that such visitors generally moved on to the larger Tri-City area after a one-night stay in lower- or moderately priced accommodation. Another stated that the local spa offer and swimming pools were attractions for some visitors, but they were not on the same scale as those available in larger towns. Another respondent living in the town stated that although the amenities offered by Braniewo were quite diverse - she mentioned the small but well-maintained zoo and the newly built swimming pool - they could not compete with larger cities and towns as far as attractions for Kaliningrad residents were concerned. For those respondents, proximity was more important than the actual quality or abundance of goods.

There is a discernible digital divide when comparing Internet home pages for many of the attractions offered in Braniewo with those of larger towns. Braniewo lacks Russian-language web pages for many, if not most, of its local businesses and attractions. The most comprehensive pages in Russian are those of the Hotel Warmia and the IM Service package transporter. Numerous questions concerning the town and the services it offers can be found on the Kaliningrad forum and list sites ${ }^{1}$. Those are usually basic questions about the location of shops, the availability of goods, and opening hours during holidays.

There have been some negative reactions to changes brought about by visitors. The main complaint is not of a political nature, but usually concerns queues in local shops, pollution, and car traffic. When politics does become a topic of conversation, it is quickly brushed aside to avoid confrontation (Where Poles and Russians meet, ideals and profits clash, 2015). One local resident glibly summed this up by stating that although Braniewo was not Ukraine, it still had to deal with a Russian invasion on a daily basis ${ }^{2}$. Some complaints, such as the fear that the neighbouring border-crossing point made Russians bypass Braniewo for larger towns and thus caused the town's economy to suffer, often followed

\footnotetext{
1 polsha.pl offers a small list of shopping options in Braniewo, but with more questions than answers about what is available.

2 Shopper, Biedronka, July 2014.
} 
complaints about pollution, lack of retail parking space, or politics. The assumption that the larger border crossings cause the town to be bypassed is correct. More recently, local residents have been involved in protests against the transit of cheap Russian coal from Kaliningrad near the town. This has increased tensions in the town (Protest in Braniewo, 2015).

A number of business respondents were openly hostile towards Kaliningrad residents in private, but offered them goods and services in public on an equal, non-discriminatory basis, stating that the trade was profitable and worthwhile. One local resident joked: "You wouldn't find a person in town who will say something bad about a Russian, at least not in front of him" ${ }^{\prime 3}$. Many residents believe that travelling to Kaliningrad has little to offer them beyond the petty petrol trade or basic goods. Likewise, the suggestion of offering tailored Russian digital advertising or creating a local Russian-language digital media to increase profits is met by some with surprise and by others with scepticism ${ }^{4}$. From the Polish perspective, the psychology of the past and some fear concerning the future dissuades many from venturing more than a few kilometres into Kaliningrad or offering a more comprehensive service in Russian.

\section{Tri-City as part of the border region}

Since 2012 Tri-City has been formally included in Poland's border zone scheme. This came about when the agglomeration authorities began to look towards the Kaliningrad Oblast, through the organisation of economic forums, as a possible partner of cooperation. Officials tried to find common ground and work more closely with their north-eastern neighbours.

Tri-City is two or three hours by car from the city of Kaliningrad (depending on the situation at the border). The agglomeration is the

Local tradesman, July 2014.

4 Taken from interviews in August 2014. One local business owner saw this as a good idea, but wondered whether it was worth the investment in the end. Others stated that there was little need for such things for Russians. One local resident went so far as to state that most Kaliningrad citizens did not use the Internet to a high degree and instead relied more on word of mouth from friends and acquaintances. most popular destination for residents of the Kaliningrad Oblast. With the visa-free initiative of July 2012, there was a sudden increase in the number of visitors from the Kaliningrad Oblast to Tri-City.

The most popular reason for visiting Tri-City is shopping. Since the inception of the SBT zone in 2012 there has been a considerable increase in interest among Russian consumers in the shopping possibilities of Tri-City. The results of the authors' questionnaires show that $80.3 \%$ of the residents of the Kaliningrad Oblast cross the border to shop. According to the manager of one of the shopping centres, "After the establishment of the SBT zone, we noted that $5 \%$ of cars on the centre's premises came from Kaliningrad." The factors encouraging Russians to cross the border to shop, as listed by stakeholders, were as follows: low prices, product diversity and availability, and a higher standard of services purchased. Tri-City has become a favoured commercial destination for Kaliningrad citizens. Many commercial enterprises located in the immediate vicinity of Tri-City have reported a considerable increase in income. To sustain this growth, managers of shopping centres have created information signs in Russian (Fig. 4). Leaflets and basic information in Russian have become a visible strategy designed to encourage Kaliningrad citizens to make purchases in the Tri-City shopping centres.

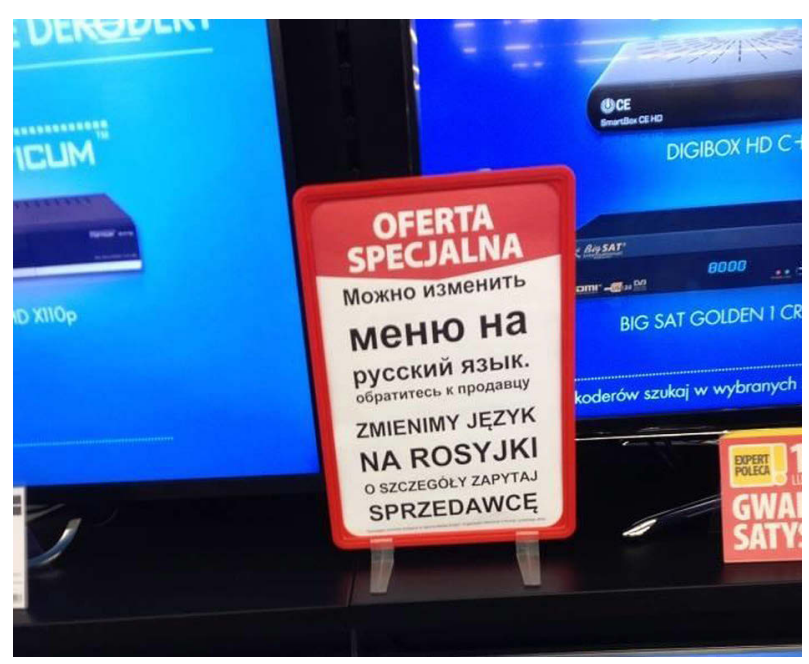

Fig. 4. Russian- and Polish-language sign for digital TV boxes "SPECIAL OFFER: We will change the menu to the Russian language. For details please ask the salesperson". Source: own collection. 
All product information in the popular furniture megastore IKEA has been made available in Russian to facilitate shopping. According to one of the shop assistants, "English isn't a language Russians use, and the staff's knowledge of Russian is very limited. Therefore, to facilitate our work and Russians' purchases, information about the available products and further instructions has been translated into Russian."

Russians constitute the largest group of foreign visitors whose main reason for coming to Tri-City is shopping. A great majority of Russians cross the border by car, which makes shopping considerably easier. There are also frequent crossings by bus and minibus. These take visitors from Kaliningrad directly to the main shopping centres (Fashion House, Auchan, CH Osowa, etc.).

More than $40 \%$ of the respondents visited the Tri-City area several times a month, and about $32 \%$ visited the agglomeration several times a year (Fig. 5). This demonstrates Tri-City's popularity. It is treated by many citizens of the Kaliningrad Oblast as the most easily accessible large European centre. The most popular shopping periods are weekends, especially before Christmas and at the beginning of the spring and autumn seasons. During those periods clothes and shoes are the dominant purchases. Russians also combine their shopping in Tri-City with visits to the zoo, aqua park, or theatre.

Before the implementation of the SBT regime Kaliningrad citizens' most popular way of travelling abroad was through group holidays organised by travel agencies. After 2012 and the inception of the SBT zone, these were replaced by short trips (1-2 days, Fig. 6). The removal of visa requirements and hotel invitations contributed to a growth in arrivals of individual customers travelling without a set plan. Such travellers were more likely to explore the city. They were also more willing to discover new places and tourist attractions inside the Tri-City area.

According to the majority of respondents $(95.7 \%)$, Tri-City's tourist infrastructure is well developed. More than $66 \%$ of the Russian respondents choose to stay in Gdańsk. Gdynia is less popular, with only $12.8 \%$ of the respondents staying there overnight.

Apart from sightseeing, event, medical and sports tourism are also developing. Event tourism is centred mainly on concerts by world-famous stars and visits to the musical theatre in Gdynia, the Baltic Philharmonic Orchestra in Gdańsk, and events held in two sport halls (Ergo Arena between Gdańsk and Sopot and the entertainment hall in Gdynia). As to sports tourism, there is considerable interest in water sports and car racing. According to a worker in the tourist organisation, Russians constituted the majority of the spectators at a recent speedway competition in Gdańsk. There is also a notable growth of interest in medical tourism; cosmetic surgery and dentistry are especially popular. Advertising for those medical services is often targeted at Russian customers.

To attract a higher number of Russian tourists, Pomeranian voivodeship and the cities of the Tri-City agglomeration launched an active promotional campaign in the Kaliningrad Oblast after 2012. A research conducted by the Gdańsk City Office indicates that Kaliningrad citizens perceived Tri-City as an attractive place to visit.

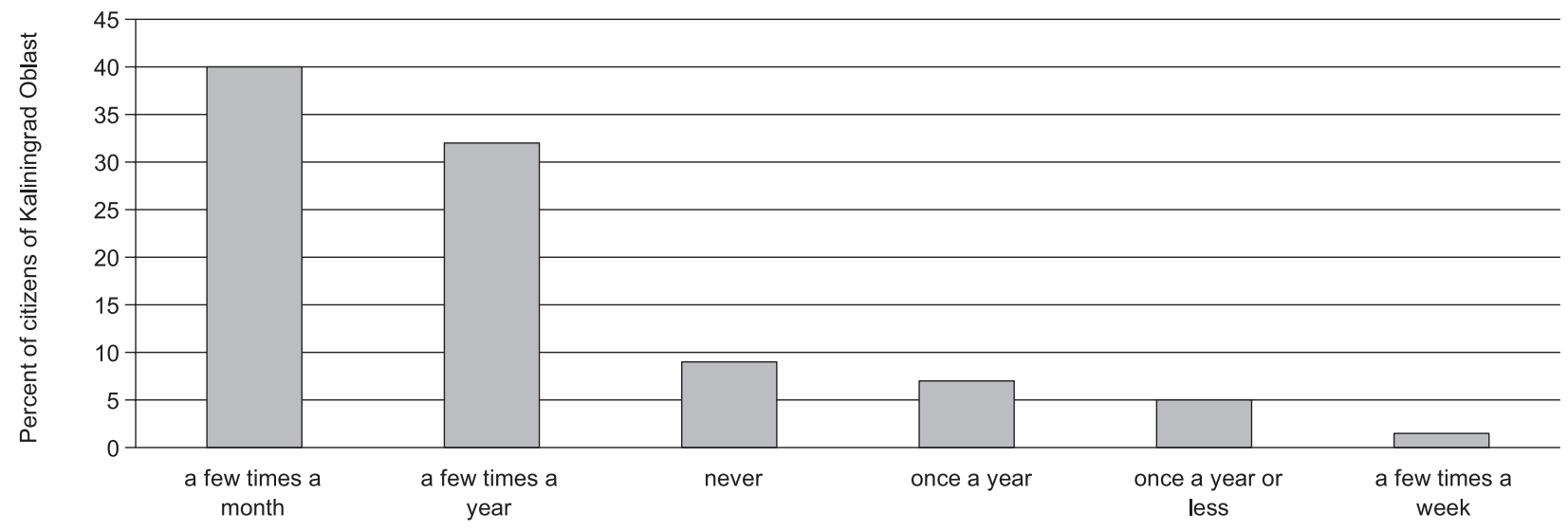

Fig. 5. Frequency of visits to Tri-City by citizens of the Kaliningrad Oblast. Source: authors' questionnaire. 


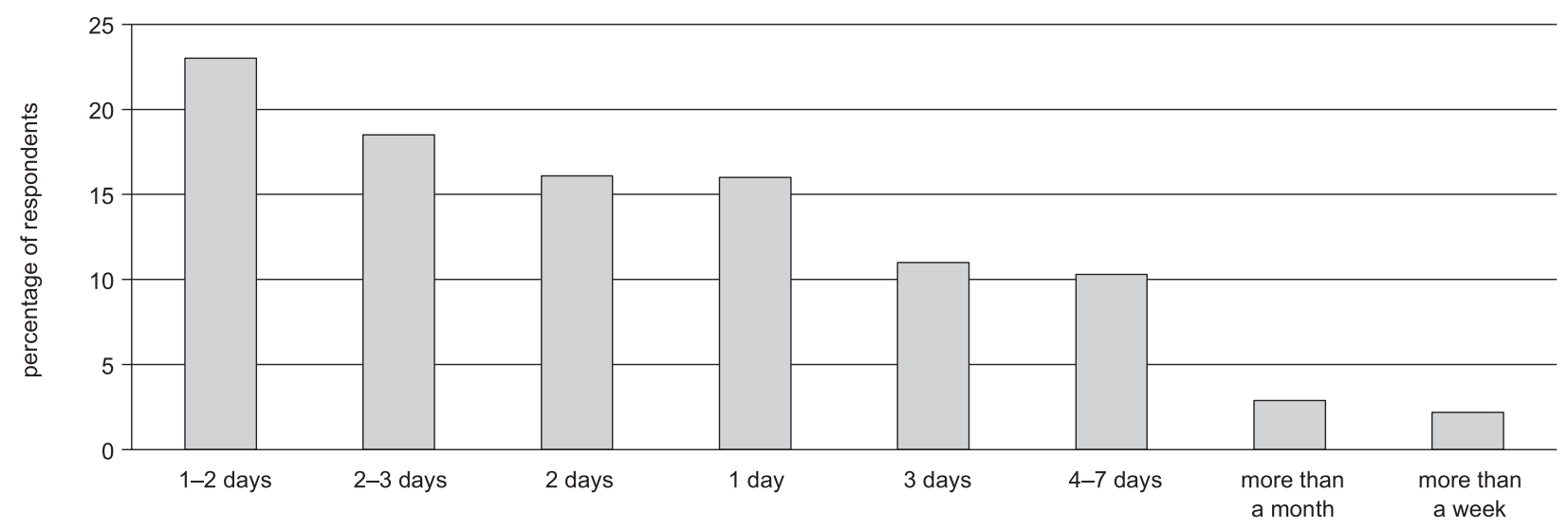

Fig. 6. Length of stay of Kaliningrad Oblast citizens in Tri-City.

Source: authors' questionnaire.

Their knowledge of Gdańsk is significant and growing as a result of their frequent and regular visits to the city.

The most popular ways of advertising the region are through visits by Russian journalists to Tri-City and newspaper supplements (including Kaliningradskaya Pravda, Dvornik, etc.). They usually promote tourist attractions and events held in the agglomeration. Advertisements are also shown on local Russian television stations like TV Kaskad. The most widespread media campaigns were organised for the International Women's Day in Tri-City. They included special bargains at hotels, restaurants and shopping centres known to be frequented by Russian tourists. At the border crossing between Kaliningrad and Tri-City (Grzechotki-Mamonovo) amber hearts were handed out to women. Additionally, promotional campaigns were organised during public holidays in Russia. Among them were the Labour Day (1st May) and the Day of National Unity (4th November), when Kaliningrad residents frequently cross the border.

Before the establishment of the SBT zone Russian tourists did not constitute a significant percentage of foreign visitors. After the implementation of the agreement Russians were second only to Germans in terms of the number of foreign tourists. However, the Russian market is unstable after the annexation of Crimea by Russia, relations between Moscow and Brussels deteriorated. This had a negative impact on MoscowWarsaw relations, and cross-border movements on the Polish-Russian border began to decrease. The trend in weekend visits to Poland also weakened, and the number of Russian tourists to Gdańsk decreased. In 2014 Russians were the third largest group of visitors to the region (with Swedes) after those from Germany and the U.K., respectively (Russians' opinion about Gdańsk, 2014). However, the SBT agreement has changed Kaliningrad citizens' perception of Tri-City, and reduced the distance between the local communities of the two cities.

\section{Conclusions}

The physical border still exists at the PolishRussian borderland. However, since the small border traffic zone legislation came into force, the border has changed its blockading function and instead started to be treated as a resource. Border towns and other locations near the border have been given an opportunity for development. TriCity, included in the local border traffic zone, has also benefited from this arrangement and become part of the border region. This development has been achieved in several different, albeit strategically similar, ways. These differences are caused by the size and location of the towns vis-à-vis the border, and they have given rise to uneven growth and development.

The implementation of the Agreement on Local Border Traffic has changed the functioning of both Tri-City and Braniewo. The SBT zone gives Kaliningrad residents much easier access to northern Poland. The loosening of the border-crossing regime has reduced the social and functional distance between Poland and Kaliningrad (Domaniewski, Studzińska 2016). Weekend trips to the Tri-City region have become 
a regular activity of Kaliningrad residents, while short day trips have become the norm for Braniewo. Tri-City has also become a cultural and entertainment destination for Kaliningrad citizens. Since 2012 businesses have realised the power of foreign-language advertising. Also other border towns have introduced facilities for Russians and encouraged Kaliningrad citizens to visit the Polish border region. Tri-City has gained a lot, and has become a good example of how to benefit from the SBT zone.

Braniewo has tried to compete with larger municipalities such as Tri-City by offering amenities closer to Kaliningrad. They are often of mediocre quality and offer less diversity than that found further afield in the SBT zone. More recent trends show that larger-volume stores have moved into the area since the opening of the border. This expansion of operations reflects what occurs in other areas of the SBT zone. Furthermore, like larger municipalities, Braniewo offers services in Russian, but in this respect there are technological gaps in Internet and electronic advertising.

More recently, location has not been enough to attract more people to Braniewo. The number of individuals crossing to take advantage of those amenities has noticeably decreased throughout the SBT zone. This can be attributed to several factors beyond the standard political explanation. Braniewo offers Kaliningrad residents more than shopping and basic services. The issue is the size and how those offers are presented to visitors. It is understandable that Kaliningrad citizens seek more diversified, accessible, or better-quality goods, services and information than those available in Braniewo. Visitors are pulled towards larger urban centres where such things are available.

The language barrier is less significant at the Polish-Russian border, but the mental barrier continues to be an issue. This barrier is based on current political tensions as well as historical ones. It remains the principal reason Poles do not visit the Kaliningrad Oblast for more than a few hours, if at all. Tri-City residents are not at ease with Kaliningrad. According to the authors' survey, $90.1 \%$ of Tri-City respondents have never crossed the border since the SBT zone came into effect, and do not plan to do so. Whatever familiarity Braniewo residents may have with Kaliningrad is almost exclusively with the area within a few kilometres of the immediate border area.

Ultimately, the SBT zone is above all a kind of a border experiment or laboratory. For at least the conceivable future it offers its towns the capacity for change and reinvention. The critical task for those entities now and in the future is to learn from each other's mistakes and shortcomings. Secondly, smaller units have come to see the border as more of a resource and started to be more strategic in their planning concerning it. Towards this goal, larger towns can offer smaller ones a helping hand when both their interests overlap. This would help even out the current divide in development between them.

\section{Acknowledgements}

This research was part of the EUBORDERSCAPES project (SSH.2011.4.2-1-290775) funded by the European Commission under the 7th Framework Programme. It was also funded by the Ministry of Science and Higher Education from funds allocated for science in the years 2013-2016.

\section{References}

Agreement on a visa-free travel zone between Poland and Russia, 2012 (Official Gazette 2012, position 814).

Cross-border traffic at the Polish-Russian border, 2015. Border Guards, unpublished statistics.

Domaniewski S., Studzińska D., 2016. The small border traffic zone between Poland and the Kaliningrad region (Russia): The impact of a local visa-free border regime. Geopolitics 21(3): 538-555.

Donnan H., Wilson T.M., 1999. Borders: Frontiers of identity, nation and state. Oxford-New York, Berg.

Dudzińska K., Dyner A., 2013. Small border traffic with Kaliningrad: Challenges, opportunities, threats. PISM Policy Paper 29 (77): 1-7.

Hanson G.H., 1998. Regional adjustment to trade liberalization. Regional Science and Urban Economics 28 (4): 419-444.

Heffner K., 2010 . Granica - rozwój instytucji (Border - the development of institutions). In: Grochalski S.M. (ed.), Ewolucja instytucji granicy we wspótczesnej Europie. Wydawnictwo Uniwersytetu Opolskiego, Opole: 77-100.

Komornicki T., 1999. Granice Polski. Analiza zmian przenikalności w latach 1990-1996 (Polish borders. An analysis of changes in their permeability in the years 1990-1996). Geopolitical Studies 5, PAN IGiPZ, Warszawa.

Opioła W., Trzcielińska-Polus A., 2013. Fenomen pograniczy (Phenomenon of borderlands). Pogranicze. Polish Borderlands Studies 1: 6-11.

Poles in Kaliningrad, 2015. http://wiadomosci.wp.pl/ kat,1019385,title,Zaatakowali-Polakow-w-obwodzie-ka- 
liningradzkim-Zadali-pieniedzy-za-ochrone, 17381700, wiadomosc. html?ticaid=1154bf.

Protest in Braniewo, 2015. Online: http://www.tvp.info/ 16971069/gornicy-w-braniewie-blokuja-transporty-wegla-z-rosji-zadaja-od-kopacz-odpowiedzi-na-postulaty-w-jej-expos (accessed 10 June 2015).

Russians' opinion about Gdańsk, 2015. Gdańsk City Hall, Department of Socio-Economic Analysis, unpublished statistics.

Sohn C., 2014. Modelling cross-border integration: The role of borders as a resource. Geopolitics 19(3): 587-608. wid, Spierings B., Van der Velde M.R., 2008. Shopping, borders and unfamiliarity: Consumer mobility in Europe. Tijdschrift voor economische en sociale geografie 99(4): 497-505.

Studzińska D., Nowicka K., 2014. Mały ruch graniczny z perspektywy władz lokalnych i mieszkańców. Przykład granicy polsko-rosyjskiej (Local border traffic from the point of view of inhabitants and local authorities. The case of the Polish-Russian border). Prace i Studia Geograficzne 54: 275-288.

Where Poles and Russians meet, ideals and profits clash, 2015. Online: http://www.nytimes.com/ 2015/04/25/world/ europe/where-poles-and-russians-meet-ideals-andprofits-clash.html?_r=0 (accessed 10 June 2015). 